\title{
GCU
}

Glasgow Caledonian

University

University for the Common Good

\section{Assessing the validity of recent estimates of problematic drug use in England}

Frisher, Martin; Forsyth, Alasdair

Published in:

Journal of Epidemiology and Community Health

DOI:

10.1136/jech.2008.076844

Publication date:

2009

Document Version

Author accepted manuscript

Link to publication in ResearchOnline

Citation for published version (Harvard):

Frisher, M \& Forsyth, A 2009, 'Assessing the validity of recent estimates of problematic drug use in England', Journal of Epidemiology and Community Health, vol. 63, no. 1, pp. 87-88.

https://doi.org/10.1136/jech.2008.076844

\section{General rights}

Copyright and moral rights for the publications made accessible in the public portal are retained by the authors and/or other copyright owners and it is a condition of accessing publications that users recognise and abide by the legal requirements associated with these rights.

Take down policy

If you believe that this document breaches copyright please view our takedown policy at https://edshare.gcu.ac.uk/id/eprint/5179 for details of how to contact us. 
Assessing the validity of recent estimates of problematic drug use in England

\author{
Martin Frisher \& Alasdair Forsyth
}

$\underline{\text { Name, Positions \& Addresses }}$

Martin Frisher, Senior Lecturer, Department of Medicines Management, Keele University, Staffordshire, ST5 5BG, United Kingdom. E-mail: m.frisher@keele.ac.uk

Alasdair Forsyth, Senior Research Fellow, Scottish Centre for Crime \& Justice Research, Glasgow Caledonian University, Glasgow, G4 0BA, United Kingdom E-mail: Alasdair.Forsyth@gcal.ac.uk

\title{
Corresponding Author:
}

Martin Frisher,

Department of Medicines Management,

Keele University, Staffordshire,ST5 5BG,

United Kingdom

e-mail:m.frisher@keele.ac.uk

tel:01782583568 


\begin{abstract}
The Home Office has recently published estimates which, for first time, provide a "robust national estimate" of the number of problematic drug users (PDU) in England. The 2004/05 and 2005/06 estimates are the highest estimates ever produced for England and coincide with the highest ever Government annual expenditure on combating illicit drug use. This paper reviews a range of data sources that indicate a downwards trend in problematic drug use in recent years. The validity of the estimates is important for drug policy and the paper considers the implications of both increasing and decreasing levels of problematic drug use.
\end{abstract}




\section{Assessing the validity of recent estimates of problematic drug use in England}

\section{$\underline{\text { Introduction }}$}

The Home Office has recently published estimates of the number of problematic drug users (PDU) in England for $2004 / 05^{1}$ and $2005 / 06^{2}$. The first study report states that the method used "provides for the first time a robust national estimate of this important target group". Previous estimates are said to be less robust because they "had very wide confidence intervals within which the true estimate might lie". The 2004/05 and 2005/06 estimates are the highest estimates ever produced for England and coincide with the highest ever annual UK Government's direct annual expenditure on combating illicit drug use of $£ 1.48$ billion in $2005 / 06^{3}$.

However, robustness is not just a matter of confidence intervals but of the validity of the data and methods which underlie the estimates. The implication of the 2004/05 and 2005/06 estimates is that problematic drug use is at an all time high. Elsewhere the authors of these estimates discuss a scenario where problematic drug use in the UK may continue to increase to over 1 million by $2025^{4}$. However, other data sources, described below, indicate a downwards trend in problematic drug use in recent years.

The recent PDU estimates are based on two statistical techniques; the capture recapture method (CRM) and (to a lesser extent) the multiple indicator method (MIM). Both 
methods are indirect ways of estimating prevalence and rely on data on known drug users $^{5,6}$. Indirect methods are generally used for PDU, as direct methods such as population surveys have obvious limitations for this group.

CRM involves examining the overlap between lists of drug users whose identifiers are recorded by agencies such as treatment centres or the police. Essentially, the lower the level of overlap, the higher the estimate. Thus accurate identification of individuals is essential. More sophisticated versions involving multiple samples have also been developed in order to overcome the stringent assumptions which are required when only two-samples are used. MIM is a form of multiple regression analysis in which drug indicators are used to impute estimates in areas where the number of users is unknown. In simple terms, as the level of drug indicators increase, so to does the prevalence estimate.

For CRM to produce valid estimates cases should have equal 'catchability' in each source and be uniquely matched among the various data sources. MIM assumes that there is a linear relationship between drug indicators and prevalence and that this relationship is the same in all areas. The underlying robustness or otherwise of these models, therefore depends on whether these assumptions are met.

In practice these assumptions are difficult to verify. An alternative approach to evaluating robustness is to consider the criterion validity of the estimates. Criterionrelated validity includes "any validity strategies that focus on the correlation of the 
measure being validated with some well-respected outside measure(s) of the same objectives or specifications"

One way of assessing the criterion validity of the estimates is to compare trends in prevalence estimates and other measures of problematic drug use. The estimates would have criterion validity if the magnitude and direction of change in PDU prevalence estimates were similar to the change in drug indicators.

National PDU estimates for England are available for $1996^{8}, 2001 / 02^{9}{ }^{10}$.. 2004/05 ${ }^{1}$ and $2005 / 06^{2}$. Three drug indicators have data over the necessary time scale. These are a) the British Crime Survey ${ }^{11}$, b) the number of drug related deaths ${ }^{12}$ and c)the number of hospital admissions that are due to drug abuse ${ }^{13}$. All three of these indicators are potentially less biased than, for example, the number of drug offences which is more likely to be influenced by policy ${ }^{14}$. For the BCS, the most appropriate indicator is level of class A drug use in the last month.

Table 1 shows that between 1996 and 2001/02, the PDU estimate increased by $27.6 \%$. The average increase in the three indicators was 16.2\%. Between 2001/02 and 2004/05, the PDU estimate increased by $13.8 \%$ while the average decrease in the three indicators was $6.4 \%$. 
Table 1. Drug indicators and EU/Home Office PDU estimates

\begin{tabular}{|c|c|c|c|c|c|}
\hline Data & 1996 & $2001 / 02002$ & $2004 / 2005$ & $\begin{array}{c}\% \text { change } \\
1996-2001 / 02\end{array}$ & $\begin{array}{c}\% \text { change } \\
2001 / 02- \\
2004 / 05\end{array}$ \\
\hline $\begin{array}{c}\text { N of Hospital Episodes } \\
\text { in England } \\
\text { due to drug abuse }\end{array}$ & 7,509 & 8,767 & 8,684 & +16.8 & -0.9 \\
\hline $\begin{array}{c}\text { BCS: Class A use in } \\
\text { last month } \\
\text { (Est. N of users in } \\
\text { England and Wales) }\end{array}$ & 388,941 & 551,000 & 473,000 & +41.7 & -14.2 \\
\hline $\begin{array}{c}\text { Number of drug related } \\
\text { deaths in England }\end{array}$ & 2,721 & 2,898 & 2,598 & +6.5 & -10.4 \\
\hline $\begin{array}{c}\text { Average change in } \\
\text { indicators }\end{array}$ & & $\mathbf{2 8 7 , 6 7 0}$ & $\mathbf{3 2 7 , 4 4 7}$ & $\mathbf{+ 2 7 . 6}$ & $\mathbf{+ 1 6 . 2}$ \\
\hline $\begin{array}{c}\text { EU/Home Office PDU } \\
\text { median estimate for } \\
\text { England }\end{array}$ & $\mathbf{2 2 5 , 4 0 3}$ & $\mathbf{+ 1 3 . 8}$ \\
\hline
\end{tabular}

Note: the 1996 and 2001 definition of problematic drug use was 'current use of illicit opiates, crack-cocaine or benzodiazepines'; 2005 definition was restricted to "use of opiates and/or the use of crack cocaine".

The direction of change for all drug indicators between 1996 and 2001/02 is in the same direction as the PDU estimates. In contrast between 2001/02 and 2004/05, the PDU estimate increased while the three drug indicators declined.

There is also further evidence that PDU has declined in recent years. The Home Office's Drug Harm Index (DHI) mirrors the indicators reported here. The DHI incorporates measures of the harms that individuals and society suffer due to drug-related crime, the health impacts arising from drug abuse, and the impact of drug use and dealing on communities. This is achieved by using readily available published data for each of the harms, which are then combined into a single-figure time-series index ${ }^{15}$. In 1998 the index was calibrated at 100 , increasing to 120.8 in 2001 and falling to 83.8 in $2005^{16}$. 
If the DHI trend is applied to the PDU estimates, using the 2001/02 estimate as the baseline, the $2005 / 05$ figure would be 200,000 , i.e. $40 \%$ lower than the Home Office estimate. As this estimate is far outwith the confidence interval of $325,945-343,424$, the implications are either that the analysis presented here is faulty or that the data on which the 2004/05 estimates are based are not suitable for the statistical methods used.

The validity of the estimates is important for drug policy. If the 2004/05 estimates are valid they suggest that efforts to combat problematic drug use from 2001 to 2005 have not been successful, since the estimated number of problematic drug users has increased by $14 \%$ compared to the $2001 / 02$ estimate. It is possible that increasing levels of PDU could coexist with decreasing levels of drug indicators if, for example, harm reduction polices have been effective in reducing the number of drug related deaths. However, one of the authors of the recent estimates has specifically criticised harm reduction policies ${ }^{17}$ and has stated that they have "failed"18. An alternative scenario, would be that the actual PDU level is significantly lower than the published estimate which is therefore not as "robust" as has been claimed. A recent Swiss study reported that heroin substitution programmes with methadone or buprenorphine) are associated with declining incidence of heroin use in treatment in Switzerland ${ }^{19}$ perhaps because the medicalisation of drug addiction has changed the image of heroin such that it is no longer seen as an attractive drug of choice for many young people. Although the authors of the Swiss study are careful to avoid claiming that there is a direct causal association, their detailed analysis is at least consistent with this hypothesis. The analysis presented in the current paper is similarly consistent, but the cultural context of drug use in the UK is very different and 
further analysis is required to evaluate the impact of different prevention and treatment strategies.

\section{Declaration of Interest.}

MF was one of the authors of the 1996 and 2001/02 studies of problematic drug use. 


\section{Policy Implications}

While a recent Home Office study has indicated that problematic drug misuse in the England is at an all time high, this paper reviews a range of data which indicate that challenges that problematic drug misuse may well be declining To the best of our knowledge the perception of ever increasing levels of problematic drug misuse is rarely, if ever, challenged in the public health arena. As over $£ 1$ billion of public money is being allocated to combat illicit drug use, policy makers should carefully consider the true nature and extent of illicit drug use in the UK. 


\section{References}

${ }^{1}$ Hay, G., Gannon, M., MacDougall, J., Millar, T., Eastwood, C. and McKeganey, N. Local and national estimates of the prevalence of opiate use and/or crack cocaine use (2004/05). In Singleton, N., Murray, R. and Tinsley, L. Measuring different aspects of problem drug use: methodological developments. Home Office Online Report 16/06. 2006. http://www.homeoffice.gov.uk/rds/pdfs06/rdsolr1606.pdf [accessed 24/01/2008].

2 Hay, G., Gannon, M., MacDougall, J., Millar, T., Eastwood, C. and McKeganey, N. National and regional estimates of the prevalence of opiate use and/or crack cocaine use 2005/06: a summary of key findings Home Office Online Report 21/07 2007. http://www.homeoffice.gov.uk/rds/pdfs07/rdsolr2107.pdf [accessed 24/01/2008].

${ }^{3}$ Home Office. Drug Strategy. 2007 http://www.drugs.gov.uk/drug-strategy/funding. [accessed 24/01/2008].

${ }^{4}$ McKeganey N, Neale J, Lloyd C, Hay G. Sociology and substance use. State of Science Review, for Drugs Futures 2025. London: Department of Trade and Industry. 2005. http://www.foresight.gov.uk . [accessed 24/01/2008].

${ }^{5}$ Seber, G. A. F. The Estimation of Animal Abundance and Related Parameters, 2nd Edition. Blackburn Press, Caldwell, New Jersey, 1982

${ }^{6}$ Brecht ML, Wickens TD. Application of multiple capture methods for estimating drug use prevalence. Journal of Drug Issues. 1993; 23: 229-250

${ }^{7}$ Messick, S. The once and future issues of validity: Assessing the meaning and consequences of measurement. In H. Wainer \& H. I. Braun (Eds.), Test validity (pp. 33-45). Hillsdale, NJ: Lawrence Erlbaum Associates, 1988. 
${ }^{8}$ Frisher M, Hickman H, Kraus L, Mariani F, Wiessing L. A comparison of different methods for estimating the prevalence of problematic drug misuse in Great Britain. Addiction 2001; 96, 1465-1476.

${ }^{9}$ Frisher M, Heatlie $\mathrm{H}$ and Hickman M Prevalence of problematic and injecting drug use for Drug Action Team areas in England. Journal of Public Health Journal of Public Health 2006 28(1):3-9.

${ }^{10}$ Frisher M, Heatlie $\mathrm{H}$ and Hickman M. Validating estimates of problematic drug use in England. BMC Public Health 2007, 7:286

${ }^{11}$ Roe R and Louise Man L. Drug Misuse Declared: Findings from the 2005/06 British $\begin{array}{llll}\text { Crime } & \text { Survey. } & \text { England }\end{array}$ http://www.homeoffice.gov.uk/rds/pdfs06/hosb1506.pdf [accessed 24/01/2008].

12 European Monitoring Centre for Drugs and Drug Addiction (EMCDDA) is Annual report 2006: the state of the drugs problem in Europe. EMCDDA, Lisbon 2007.

13 HES Online. Hospital Epidosde Statistics: Illict Drugs. 2007. http://www.hesonline.nhs.uk/Ease/servlet/ContentServer?siteID=1937\&categoryID=95 1 [accessed 24/01/2008].

14 Home Office Police. Operation Crackdown - Final Results http://police.homeoffice.gov.uk/news-and-publications/news/pr-1108?version=1 [accessed 24/01/2008].

${ }^{15}$ Home Office. Measuring the harm from illegal drugs using the Drug Harm Index. Online report 24/05. 2005. http://www.homeoffice.gov.uk/rds/notes/rdsolr2405.html [accessed 24/01/2008]. 
${ }^{16}$ Home Office. Measuring the harm from illegal drugs: the. Drug Harm Index 2005. 2007 www.homeoffice.gov.uk/rds/pdfs07/rdsolr2207.pdf [accessed 24/01/2008].

${ }^{17}$ McKeganey, N. The lure and the loss of harm reduction in UK drug policy and practice Addiction Research and Theory December 2006; 14(6): 557-588

18 McCann, J Get treatment or lose kids, Evening Times, http://www.eveningtimes.co.uk/news/display.var.1794991.0.get_treatment_or_lose_kids. php [accessed 24/01/2008].

${ }^{19}$ Nordt C \& Stohler R. Incidence of heroin use in Zurich, Switzerland: a treatment case register analysis. Lancet 2006; 367: 1830-34 